Abstracta Iranica Abstracta Iranica

Revue bibliographique pour le domaine irano-aryen

Volume 32-33 | 2013

Comptes rendus des publications de 2009-2010

\title{
Laurianne Martinez-Sève. Pouvoir et religion dans la Bactriane hellénistique. Recherches sur la politique religieuse des rois séleucides et gréco-bactriens
}

\section{Rémy Boucharlat}

\section{(2) OpenEdition \\ Journals}

Édition électronique

URL : http://journals.openedition.org/abstractairanica/40550

DOI : 10.4000/abstractairanica.40550

ISSN : 1961-960X

Éditeur :

CNRS (UMR 7528 Mondes iraniens et indiens), Éditions de l'IFRI

Édition imprimée

Date de publication : 1 décembre 2013

ISSN : 0240-8910

Référence électronique

Rémy Boucharlat, « Laurianne Martinez-Sève. Pouvoir et religion dans la Bactriane hellénistique.

Recherches sur la politique religieuse des rois séleucides et gréco-bactriens », Abstracta Iranica [En ligne],

Volume 32-33 | 2013, document 184, mis en ligne le 01 juillet 2016, consulté le 01 octobre 2020. URL http://journals.openedition.org/abstractairanica/40550; DOI : https://doi.org/10.4000/

abstractairanica. 40550

Ce document a été généré automatiquement le 1 octobre 2020.

Tous droits réservés 


\title{
Laurianne Martinez-Sève. Pouvoir et religion dans la Bactriane hellénistique. Recherches sur la politique religieuse des rois séleucides et gréco-bactriens
}

\author{
Rémy Boucharlat
}

\section{RÉFÉRENCE}

Laurianne Martinez-Sève. « Pouvoir et religion dans la Bactriane hellénistique.

Recherches sur la politique religieuse des rois séleucides et gréco-bactriens ». Chiron 40, 2010, p. 1-27.

L'A. utilise les données numismatiques et deux temples seulement, avec leur matériel, pour aborder plusieurs sujets: les divinités protectrices du pouvoir royal, les unes grecques, les autres locales; les relations sans doute privilégiées entre les rois et les sanctuaires; le culte royal en Bactriane qui est plus un culte de la personne royale que de la dynastie. Tout cela permet de montrer une attitude des rois gréco-bactriens très semblables à celle des souverains séleucides.

\section{AUTEURS}

RÉMY BOUCHARLAT

CNRS, Lyon 